\title{
Searching for the "Old West" in the Theme Towns of the New American West
}

\author{
Eric C. Ewert a* $^{*}$ \\ aProfessor of Geography, Department of Geography, Weber State University, United States. \\ *Corresponding author's email address: eewert@weber.edu
}

\section{A R T I C L E I N F O}

Received: 10-09-2015

Accepted: 10-01-2016

Available online: 20-01-2016

Keywords:

Theme Towns, Tourism, Economic Development, American West, Old West.

JEL Classification:

\begin{abstract}
A B S T R A C T
The Western Anachronism: thanks to western novels and Hollywood, the general public and a great many foreign visitors believe that the "Real West" is, or should be, the mythic West of cowboys and Indians, pickax miners, mountain trappers, and Oregon Trail pioneers. And for a great many busted resource towns, Real West tourism seems to be the boom waiting to replace moribund mining, logging, ranching, and agriculture. So, in many places, towns have rushed to re-create the past in order to attract visitors and new residents. Tourists want to see 19 th-century saloons and bordellos, old-style signs, Main Street gunfights, blacksmith shops, and hitching posts, not irrigated agriculture, sprawling suburbs, interstate highways, franchise America, and retirement communities. To meet these expectations, towns have reinvented themselves as "museums" of the Old West. For some, historic preservation and resurrection of past landscapes have sufficed, but for others, the "old" look is completely contrived. In both cases, this "Old West" iconography has become emblematic of the rapidly growing modern "New West." It appears as Victorian, Bavarian, Mining, Wild West, Alpine, Old West, Southwest, Frontier, and other themes. Indeed, one can hardly visit a rural western town without seeing halftimbers or false fronts or board sidewalks or adobe bricks or tile roofs or some other representative adornment or period bric-a-brac. Furthermore, the activities of tourism and outdoor recreation seem most at home when rooted in these "themed" landscapes. The only problem is this: while many theme towns have enjoyed sustained economic success, the costs and tradeoffs have often rendered them no more real or stable than a western movie-set façade.
\end{abstract}

(C) 2015 The Authors. This is an open access article under the terms of the Creative Commons Attribution License 4.0, which allows use, distribution and reproduction in any medium, provided the original work is properly cited.

DOI: http://dx.doi.org/10.18533/rss.v1i1.8

\subsection{Introduction}

Western theme towns have attracted the attention of a diverse group of scholars over the years. Geographers, historians, rural economists and sociologists, development experts, urban planners and architects, tourism experts, and landscape preservationists are just a few of the many people who have found a specific fascination, and times dislike, for themed landscapes in general. Over the last several decades, this group has produced a rich and varied scholarship the ranges from deeply theoretical pieces to photo exposés and from economic enumerations to psychological studies. Historical Geographers in particular have had much to say about tourist landscapes in the western United States. Gary Hausladen has written extensively on how we think about western places based on American myths (Hausladen, 2006). David Wrobel translated those myths into reality by cataloging how promotion of memories helped create the American West (Wrobel, 2002). The authenticity or lack thereof in tourist landscapes in California has occupied several articles by Dydia DeLyser (DeLyser, 2003). 
And in a recently published book, "North American Odyssey: Historical Geographies for the Twenty-first Century," several authors tackle the topics of making mythic landscapes, shaping tourism, and creating regional identities. ${ }^{1}$ In another recently published text, now in its third edition, Stephen Williams and Alan Lew explore place, space, and experience in tourism geography (DeLyser, 2003). Mining landscapes have been treated to an especially careful analysis for years by Richard Francaviglia. In his books and articles, the idea of selling heritage landscapes often comes up (Francaviglia, 1994). Old West iconography in a New West setting has enjoyed interest from a generation of scholars now. Robert Athearn summed up an already full literature in the mid-1980s with a book devoted to "The Mythic West in Twentieth-century America. ${ }^{2}$ The capable research and writing in these areas continues unabated.

This article is not intended to be an exhaustive scholarship based on primary sources and rooted in theoretical analysis and an abundant review of the relevant literature. That work has already been done. Likewise it is in not intended to look myopically at a case study or two, but instead to look with a wider perspective, both quantitatively and qualitatively. Methodologically, this article is designed to be a broad, synthetic treatment of western theme towns from a geographer who has lived in western states from Arizona to Alaska, traveled and researched extensively in the region, and read from a wide range of sources. There is a voluminous wealth of journal articles, newspapers, magazines, promotional literature, tourist brochures, maps, and census data that touch on these topics. Rarely, though, are these disparate sources constructively summarized in a way that may illuminate patterns across space and time. This article endeavors to fill that breadth gap for more of a literate but not necessarily scholarly audience. In the process, the author plans to sort out the choices, developments, and consequences of theme towns, document their costs and benefits, and hopefully, raise awareness to promote better decision making. What follows is systematically organized in a topical way, such that the reader tours theme towns in the West with particular ideas explained, demonstrated, and contextualized. That at least is the intent of these next many pages.

\subsection{The rise of themed towns}

"The bordello is over there," says Larry Link, gesturing to a dilapidated shack he is renovating. Two and half decades ago, in 1988, Larry and Linda Link bought the railroad ghost town of Steins, in southwestern New Mexico, for $\$ 50,000$. They did not necessarily buy it out of some great love for the old towns of the West, but to develop it into a tourist attraction. Steins is within range of busy Interstate ${ }^{10}$, and the Links envisioned some of the thousands of cars streaming by each day, detouring to wander around the town's adobe, stone, and wood buildings. For $\$ 2.50$, Larry still gives a lively tour of Steins' moldering artifacts and a thorough history lesson of the area. And for twenty-five years now he has delivered that introduction, hoping that it would compel the tourists to spend the night in the attached R.V. Park or shop in the Steins Mercantile. Wrapped up in this quarter century entrepreneurial vision, the Links expected to get rich. And they're still waiting (Barrett, 1993). The elusive tourism boom has not yet returned to busted Steins. But Steins is atypical. In other places throughout the West, dozens of towns and thousands of entrepreneurs have struck it rich by capitalizing on the public's seemingly insatiable appetite for western historical imagery, especially that tied to nineteenth century western townscapes. While Steins hasn't yet reached its potential, elsewhere in the New West, looking like the Old West has proved very lucrative.

Economically, the extractive, natural resource-based economy of the Old West is in decline, and it has been for decades. The mythology of the Old West however - and the town landscapes associated with that old economy remains viable and very profitable. Today, mining, logging, ranching, and agriculture no longer significantly contribute to the economy of the West in terms of jobs and revenues. A more complex and diverse development engine replaced them with services, technology, information, retirement, and leisure. These and related industries are associated with what many call the "New West." And it is this New West that has led the country in nearly every measure of demographic and economic growth since the middle of the twentieth century (Ewert, 2006). Beginning in the post-WWII era, and accelerating especially in 1970s, 1990s, and 2000s, this New West has appealed to a plentiful new breed of rural western folk: tourists, recreationists, retirees, urban refugees, and high technology migrants. This mobile group often votes with its dollars and its residential addresses for places rich in Old West iconography. For busted natural resource towns then, transforming historic bordellos into boutiques, mine tailings into ski hills, and logging roads into mountain bike trails, can conjure economic boom out of bust. And for many towns, this involves a development strategy that necessitates organizing around an Old West-styled (or pseudo-western) "theme." Frontier, Pioneer, Mining, Wild West, Alpine, Bavarian, or Southwest themes are the most common. Yet, while many towns have enjoyed sustained economic success with this approach, the

\footnotetext{
${ }^{1}$ Blake, K.. (2014). "Making Mythic Landscapes," Wyckoff, William. (2014). "Creating Region Landscapes and Identities" and Youngs, Yolanda. (2014). "Shaping Tourism" in Craig E. Colton and Geoffrey L. Buckley, eds. North American Odyssey: Historical Geographies for the Twentyfirst Century. Lanham, Maryland: Rowman \& Littlefield.

${ }^{2}$ Athearn, R. G. (1986). The Mythic West in twentieth-century America. Lawrence: University Press of Kansas.
} 
tradeoffs and costs of adopting a theme have often so undermined the integrity of the original community that, in the end, it more resembles a western movie set facade than a real town.

\subsection{The western anachronism}

Historian Frederick Jackson Turner's vision of the western frontier as the crucible of the American character - a view debated by New and Old West academics - is of little concern to the general American public. For them, the West is still the mythic West of the nineteenth century: Manifest Destiny, cowboys and Indians, solitary pickax miners, heroic mountain trappers, and Oregon Trail pioneers. To the public, this is the "real" West. Explorers, writers, artists, and Hollywood have all combined to create this West, a West locked in images and themes that are now well more than a century past. As the region rode into the twentieth century sunset and now finds itself at the dawn of the twenty-first century, it is in many ways, still understood in terms of its nineteenth century landscapes and lifestyles. With this understanding, the historic imagination skipped the twentieth century altogether. So popular is the anachronism of the Old West that many Americans (and almost all foreign tourists) have come to expect it when they visit the region. Their expectations manifest themselves in the built environments of the western landscape. In numerous locales then, towns have reinvented themselves as "museums" of the Old West. For some, which date back to this earlier period, historic preservation and resurrection of authentic landscapes have proved possible. But for other theme towns, the 19th century look is completely and utterly contrived.

In the American West, these theme towns are scattered widely among the region's stunning natural landscapes. From the Pacific coast east to the crest of the Rockies, and from the desert Southwest north through the basins and plateaus stretching to Canada, Old West theme towns have taken root. A close examination of the geography, history, and development of these western theme towns reveals much about the economic and demographic forces shaping the region and its residents. It details the inexorable rise of the New West, and just as surely documents the enduring popularity of the Old West as a landscape and a lifestyle. The examination also clearly illustrates a host of negative trade-offs for towns and residents alike that come with rallying around an historic western theme. Loss of culture, outside ownership and control, upwardly spiraling cost of living, and environmental degradation make the short list of worrisome outcomes to this sort of development. But the lure of a tourist-driven boom is mighty powerful, especially for towns locked in the malaise of demographic and business bust. This economic enticement, combined with the popular mythology of the Old West, is so powerful in fact that western theme towns have even been built where none historically ever existed.

One such town, on the Yellowstone Highway two and a half miles west of Cody, Wyoming, is "Old Trail Town." Old Trail Town bills itself as a "Museum of the Old West." Its authentic blacksmith shop, post office, schoolhouse, creaking boardwalks, and the two-room cabin where Butch Cassidy and the Hole-in-the-Wall Gang hid from the law, did not exist on the site until moved there by Terry and Bob Edgars beginning in the late 1960s. Earlier, the Edgars had watched in horror as collectors, antique dealers, and souvenir poachers began dismantling cabins and hauling away truckloads of pioneer artifacts from the Cody area. "We realized that the historical materials out here were in more danger of being lost than buried archaeological sites," explained Bob, a former Buffalo Bill Historical Center archaeologist. Determined to preserve history, the Edgars began to scour the region for structures, farm implements, and assorted material remains of the Old West. These they relocated to a site that would become Old Trail Town. The townsite now boasts 26 buildings dating from 1879-1901, one hundred horsedrawn vehicles, and scores of Native American artifacts and frontier West memorabilia. ${ }^{3}$ Old Trail Town even solicited and won the remains and reburial of seven frontier characters for the new town's "old" cemetery. One, army scout John "Liver Eating" Johnson, attracted the reburial after the Robert Redford film spurred interest in his life. For the many fans of Jeremiah Johnson the movie, his final resting place in Santa Monica, California, mere yards from a freeway, seemed inappropriate for an intrepid mountain man. In 1974, before a crowd of more than 2000 people, the scout's remains, with Redford serving as a pallbearer, were relocated to the much more appropriate Old Trail Town cemetery. Today, Yellowstone-bound tourists stop in Old Trail Town to see the West as it really was - or as it should have been. ${ }^{4}$

\subsection{Transportation and western tourism}

Tourism especially drives theme town proliferation. And tourists' expectations influence decision making. Tourism's presence in the West harkens back to the 1800s and traces its growth and evolution primarily through innovations in transportation. As transportation to the region improved, more people visited. Wealthy railroad travelers in search of spectacular scenery and opulent accommodations were at the vanguard of this movement. Most of the country's residents however, awaited the inexpensive automobile and expanding highway network

\footnotetext{
3 Old Trail Town. "See the Old West as it Really Was," Homepage: http://oldtrailtown.org/, accessed, January, 2016.

${ }^{4}$ Merritt, J. (1992). “Down-Home and Hands-On,” Americana, June, 24-30.
} 
before they joined the tourist rush west. These two innovations, the car and the road, facilitated a virtual explosion of western visitors and greatly democratized the tourist experience. Yellowstone for example, saw its visitorship balloon from fewer than 100,000 in 1920 during the railroad era, to more than a million by 1950, when most people arrived by automobile. Yosemite National Park experienced an identical ten-fold increase over the same time period. ${ }^{5}$ With these tourists however, came a vision of the West as it appeared in popular dime-store novels and Hollywood westerns. To the post-war visitors, these images were the "Real West." The region's scenic splendor certainly lived up to their expectations, but often the settlements and the region's inhabitants did not. Tourists wondered what had happened to the cowboys and Indians, saloons and bordellos, boom mining towns, Main Street gunfights, wild horses, tumble weeds, and rattlesnakes. They most assuredly did not come to see irrigated agriculture, sprawling suburb-dominated cities, Interstate Highways, New Deal projects, war industries, franchise America, and retirement communities. While the latter were the landscapes and realities of the middle twentieth century West, visitors preferred the romantic look and lifestyle of the past century. In fact, they demanded it. Realizing this, the West's villages, towns, and even cities quickly began to invest in resurrecting their history or, if none existed, they simply created a suitable past.

In 1989, in an attempt to address tourist disappointment in the city, the mayor of Cheyenne, Wyoming, recommended that the town's residents dress in western wear and greet visitors with an exuberant "howdy" instead of just an uninspired "hello." The townspeople also pitched in to stage occasional gunfights in the streets, and visitors were invited to "Live the Legend" that is Cheyenne's slogan and to enjoy the "Frontier Days" that has become Cheyenne's signature event. ${ }^{6}$ And the tourists loved it. As it turns out, history for many is much more about perception rather than reality. This is especially true if the authentic history is not quite up to Hollywood standards and tourists' expectations.

\subsection{Heritage tourism and theme towns}

Many western theme towns are part of a surging national trend toward "Heritage Tourism," an economic spin-off of the historic preservation efforts widely undertaken in many of parts of the country beginning in the 1950 s. Heritage Tourism is defined as "traveling to experience the places, artifacts, and activities that authentically represent the stories and people of the past." It "can include cultural, historic, and natural resources." 7 In theory, with heritage tourism, visitors enjoy the usual entertainment aspects of tourism - sightseeing, recreation, dining, and shopping - but also partake in a bit of historical education and, hopefully, spend a lot of money. It is estimated that in 2014, the travel and tourism industry contributed $\$ 458$ billion to the U.S. economy, and that 81 percent of the travelers engaged in some sort of cultural or heritage tourism while they traveled. ${ }^{8}$ Obviously, the income potential for a history-themed town is enormous.

Of course, the idea of using historical landscapes as a money maker is nothing new. Since the late 1920s, John D. Rockefeller's restored colonial Williamsburg, Virginia, has attracted hordes of tourists in search of more than just entertainment. At times, the crowds can be so overwhelming in Williamsburg that some have called it "a sort of Disney World of American history." (Bryson, 1989). With such obvious success, the Wells brothers' Old Sturbridge (New England style) Village in Massachusetts, and Henry Ford's Greenfield (historic) Village in Dearborn, Michigan, soon followed. Since then, colonial settlements, Revolutionary and Civil War battlefields, municipal historic districts, early industrial areas, and Native American sites have all become popular tourist destinations. Even themed neighborhoods, like Chinatowns or Little Italies in large eastern urban areas, have long attracted visitors, so it was only a matter of time before this heritage tourism trend seeped westward (Boyer, 1992).

Virginia City, Montana, was perhaps the first to imitate this living museum concept in the West, creating what one writer called, "the Williamsburg of the West." (Spude, 1996). Interest in preserving the history of Virginia City was first discussed in 1899 at the annual meeting of the Montana Historical Society. By the 1920s, Virginia City's gold seams had largely played out, but its boom mining town architecture and 1800s-era ambiance had attracted a few curious tourists for more than two decades. Seeing the tourism possibilities, the town began to mine that new revenue stream in earnest. According to Montana's official state website, in Virginia City, heritage visitors can tour 100 historic buildings complete with artifacts and furnishings, ride the 1910 steam locomotive, drive the stagecoach, and attend a live historic theater show. They can also shop, dine, stay the night, and spend a great deal of money. ${ }^{9}$

On a summer weekend, Virginia City may be as busy today as it was in the 1860s when gold fever seized the town.

\footnotetext{
${ }^{5}$ National Park Service, “National Park Service Visitor Use Statistics,” NPS: https://irma.nps.gov/Stats/, accessed, January, 2016.

${ }^{6}$ Denver Post. (1989). "Not-So-Wild' West Disappointing," July 2.

7 National Trust for Historic Preservation, "Heritage Tourism," http://www.preservationnation.org/information-center/economics-ofrevitalization/heritage-tourism/\#.VpmzCk8kRAM, accessed, January, 2016.

${ }^{8}$ U.S. Travel Association (formerly the Travel Industry Association). (2003). "The Historical/Cultural Traveler.” Washington, D.C.: US Travel Association.

${ }_{9}^{9}$ Montana Heritage Commission, “Virginia City,” http://www.virginiacitymt.com/, accessed, January, 2016.
} 
At its peak, in 1864, the town claimed to have some 10,000 people in its immediate vicinity. By the 1870 s though, with much of the gold used up, the town only claimed a few hundred hardy souls. When Congress assigned the National Park Service responsibility for surveying historic areas of national significance, the agency reported that in the late 1930s, 6,500 tourists were already visiting Virginia City each summer. Today, 70,000 people visit Virginia City each year. That success is contagious. Beginning in the early 1960s, and just a mile and a half away from Virginia City along the original rich placer gold deposits of Alder Gulch, neighboring Nevada City has transplanted 100 historic buildings from locations all over Montana to both accommodate tourists' desires and create, or re-create, a historic landscape for them to explore and enjoy. ${ }^{10}$ Most visitors are untroubled by the fact that most of Nevada City is inauthentic, at least by geography. Both towns are wildly popular and prodigious money makers, and throughout the rural West, other towns emulate Virginia and Nevada Cities' development strategy even if they have strayed far from the original idea of heritage tourism.

What makes western theme towns so compelling then, is their stunning proliferation and especially their association with the Old West of the nineteenth century. It now seems that nearly every town with aspirations for a tourist-based economy needs to have some theme to organize around. More often than not, the theme is some variation of "western." Pioneered by the original settlers or manufactured if necessary, and codified by the media, the themes are now rather recognizable: Frontier, Pioneer, Mining, Wild West, Old West, Southwest, et cetera. One can hardly visit a town without seeing hitching posts or false-fronted buildings or adobe bricks or tile roofs or oldstyle signs or some other representative adornment or period bric-a-brac. Some of this is heritage tourism, but some of it is pure make believe.

Disney's "Frontier Land" and Knott's "Berry Farm" for example, stereotyped the mining town image for the public and allowed it to be replicated over and over again in the region's theme towns. Carried by the media and popular expectations, other themes have proliferated similarly (Francaviglia, 1994). At Knott's Berry Farm, "the park's original attraction ["Old West Ghost Town"] is a collection of authentic 19th-century buildings relocated from deserted Old West towns in Arizona and California." Once in the theme park, claims the brochure, "you can pan for gold, ride an authentic stagecoach, take rickety train cars through the Calico Mine, and get held up aboard the Calico Railroad." A wooden roller coaster dubbed "GhostRider" completes your Wild West experience. So successful was the 1940-built Ghost Town, that Knott's added "Fiesta Village," a re-creation that "suggests" old Spanish California, "Indian Trails" to showcase Native American culture, and "Wild Water Wilderness" which purports to be "styled like a turn-of-the-20th-century California wilderness park with a raging white-water river, cascading waterfalls, soaring geysers, and old-style ranger stations." 11 Whether any of these re-creations and stylizations is truly accurate or not, really makes no difference to the average amusement park visitor. But these landscape creations do firmly solidify tourists' views of what the West should be like. And thus, no matter where they travel in the region, they expect to see these landscapes.

Gambling towns form an important subset of heritage-based theme towns. Historic preservation efforts received a big boost in the post-WWII years, especially in western mining towns. As their centennial anniversaries approached, many mountain towns founded between the 50 -year bookends of the California and Klondike Gold Rushes (1848-1898) attracted preservation efforts. A few such as Aspen, Colorado, and Park City, Utah, had already successfully made the conversion to ski resorts, second home sites, or state parks, but others, the majority of these mining towns, continued to languish. ${ }^{12}$ With the 1966 passage of the National Historic Preservation Act though, federal, state, and private monies allowed these towns to resurrect their nearly forgotten history and with it, attract visitors. For many settlements, an essential part of that "Wild West" history was gaming.

Numerous towns turned to small-stakes casino gambling in order to rejuvenate their stagnant economies. The Black Hills gold mining town of Deadwood, South Dakota, approved casinos in 1989. The turnaround was remarkable. According to one author, "Deadwood went from boarded-up to booming almost overnight." Just six years later, in 1995, \$150 million was spent in Deadwood by the 2 million tourists who visited (Manning, 1996; Piner and Paradis, 2004). In 1992, three former mining towns in Colorado - Black Hawk, Central City, and Cripple Creek - enjoyed a casino-fueled economic boom reminiscent of their former gold rush glory days. In just their first year, the three towns' revenue increased $\$ 20$ million from gaming taxes, licenses, and applications. ${ }^{13}$ Local residents worked to recreate the towns as they looked in the late nineteenth century. For many, gambling - be it slot machines, roulette wheels, card tables, and even anachronistically, video poker - appeared more appropriate and indeed more acceptable if tied to these historic landscapes. For them, it just seemed more palatable to have the gambling take place in re-creations of nineteenth century saloons, with card dealers in period costumes and

\footnotetext{
${ }^{10}$ Montana Chamber of Commerce, “Virginia City,” http://virginiacity.com/\#, accessed, January, 2016.

11 Frommer's Destination Guides, “Anaheim and Disneyland,” http://www.frommers.com/destinations/anaheim-and-disneyland/774739, accessed, Feb., 2014.

12 Spude, "Looking Back...," 7.

${ }^{13}$ National Civic Review. (1993). “Distressed Cities Increasingly Bank on Casino Gambling,” Volume 82, Number 3, Summer, 302-305. Raento,

P. (2001). "Gambling in the Rocky Mountains," Geographical Society of Finland: Fennia 179(1), 97-127.
} 
player pianos belting out the tunes of the era. Not every hand is a winning hand though, and these towns have lost some sizable bets in the game of tourist dollars. The enduring viability of period gaming shall be known for sure when the main Las Vegas Strip adds its own version of a high-end "Old West Theme Town" to complement its themed re-creations of Paris, Venice, New York, and Egypt.

\subsection{Spread of theme towns}

Likely the first sizable town to realize the value of its cultural heritage was Santa Fe, New Mexico. Bypassed by the AT\&SF Railroad in the 1880s, Santa Fe had lost more than 20 percent of its population by 1910 . Without the vital rail link to the outside world, the town's future appeared rather dim. Santa Fe's fortunes began to change when Edgar L. Hewett, a fired president of the New Mexico Normal School and an archeologist by training, arrived in 1903. Hewett was an unabashed promoter and entrepreneur who quickly saw the value and marketability of Santa Fe's Native American and Hispanic cultural heritages. By extending invitations to his archeology excavations as well as making gifts of artifacts, he nimbly established ties with scholars, business leaders, and government officials. In 1907, based in part on Hewett's lobbying, the Archeological Institute of America's School of American Archeology located in Santa Fe. With an eye toward attracting tourists, Hewett then founded the Museum of New Mexico and Museum of Fine Arts, revived the Indian Market Fair and Santa Fe Fiesta, and helped establish Bandelier National Monument. Most significantly, according to one prominent historian, he co-authored "the [architecturally] restrictive code that allowed Santa Fe to retain its now 'pseudohistoric character"' making in Santa Fe, "a town where the mythic and real were purposely indistinguishable." (Rothman, 1996).

With these developments, Santa Fe's adobe future began to take hold. Soon the "City Different" attracted an AngloAmerican artistic community and counted among its illustrious members Mary Austin, Ansel Adams, and later, Georgia O'Keefe. These luminaries lent an air of legitimacy to the Santa Fe experiment. Before long, the Santa Fe mystique became a firmly established reality and the high desert town began to grow. Santa Fe ably demonstrates that successful themes are about the people and the place, the lifestyle and the landscape, and the expectations and the experience. So successful and ubiquitous is the theme today that few Santa Fe residents realize that it is not representative of the community's authentic history. And the city's tourists never question whether Santa Fe is indeed the Real McCoy (Wilson, 1997). When discovered though, this cultural facade may rub more than historians the wrong way. It may leave residents and visitors feeling duped. For the residents who interact with the tourists, they now join the props of the architecture as merely actors among the sets, not genuine people. This can lead to an unsettling disconnection with a place and its people.

Nevertheless, many other western towns have followed Santa Fe's successful lead: Deadwood and Keystone, South Dakota; Dodge City, Kansas; Kellogg and Ketchum, Idaho; Leavenworth, Port Townsend, and Winthrop, Washington; Solvang, California; Tombstone and Bisbee, Arizona; Sisters, and Junction City, Oregon; Silverton and Telluride, Colorado; Park City and Moab, Utah; Jackson Hole, Wyoming; and many others. The secret of these towns' economic success was providing what visitors expected. And typically, what the visitors expected was the look of the Old West - the "Real West" to them. Usually a direct connection to the Old West allowed a town to renovate its Victorian architecture or laud its mining or frontier history. In some towns though, the theme had nothing to do with the town's true heritage. Leavenworth, in central Washington State, is perhaps the West's best known example; its handsome Bavarian theme is completely and altogether contrived.

While not strictly a town with a western theme, Leavenworth's experience is so archetypical, so emblematic of other towns, and so thoroughly studied that it demands mention. By the early 1960s, Leavenworth's logging industry was moribund. Committees and planning groups formed and solutions to the town's woes were solicited. Tourism quickly rose as the economic salvation, and a consensus emerged that in order to attract tourism, especially from burgeoning Seattle, the town needed to remake its image. The rise in outdoor recreation activities such as camping, fishing, and boating was already attracting visitors to the area, but they simply passed through Leavenworth on their way to some other destination. What was needed, town leaders exclaimed, was something to keep visitors in town. And an attractive theme seemed to be the answer. Several themes were suggested: Western, Gay Nineties, and Alpine. For inspiration they turned to Solvang, California, the "Danish Village" located near Santa Barbara. Shortly after WWII, Solvang had cultivated a Danish theme in both architecture and ambience, and enjoyed great success. Earl Peterson, one of Solvang's principal architects, was recruited to help Leavenworth's residents realize their own vision or more specifically, "version" of the past (Frenkel and Walton, 2000).

For half a century now, Leavenworth has nurtured its Bavarian architecture, festivals, signboards, and image despite having no direct linkage to southern Germany; neither its founding residents nor most of its current citizens trace their ancestry to Bavaria. "There is not one historical museum or landmark within the boundaries of the town," noted one historian (Sudderth, 1997). The visiting tourists do not seem to mind though. In fact, 
Kellogg, a busted silver mining town in the panhandle of Idaho, has virtually copied Leavenworth's successful efforts, setting off, between the two mountain villages, a town rivalry and animosity worthy of the Hatfields and McCoys.

One professor of geography and an expert on tourism captured the competition between theme towns in a presentation titled, "Defining Place Authenticity: My Heritage Can Beat Up Your History." In the battle for tourist revenue, the claim of authenticity may translate into economic success or economic ruin. ${ }^{14}$ But it does not have to be that way. As two geographers noted in a 2000 article, "many a small town across the United States, faced with a declining resource-based economy, has turned to "theming" as an economic-development strategy. In hopes of creating an alluring landscape, the built environment is radically transformed, and a variety of invented traditions are instituted...but it is all a facade." ${ }^{15}$ And as one historian put it, "Touristic representations need only invoke a semblance, or a 'simulation,' of an imaginary past to be effective. Authenticity is hence not always the key issue...[and] in representing a past wrapped in multiple layers of mythology, you can get away with a great deal in the West." (Wrobel, 2001).

\subsection{Outdoor recreation and theme towns}

By many measures, western recreation and western theme towns grew up together, as inseparable as the Lone Ranger and Tonto. Pioneered by the skiing industry, where image is so important, entrepreneurs cultivated an Alpine European look to their ski accommodations. In 1933, Sun Valley, Idaho, was the first winter resort to organize around an Alpine theme. Skiers came to expect this facade, and as the popularity of the sport grew in the 1930s and 1940s, the theme proliferated throughout the Rockies, Cascades, and Sierra Nevada. Other ski resorts have adopted this Alpine theme too, and winter visitors have come to expect it. While not originally western, the Alpine motif is now found so ubiquitously throughout the West's ski areas that it "feels" western, and is anticipated whenever one visits the mountains to go skiing. ${ }^{16}$

In addition to skiers and their alpine towns, hunters, hikers, anglers, mountain bikers, river rafters, bird watchers, campers, equestrians, off-road vehicle drivers, and a host of other outdoor recreation enthusiasts have demanded their own "western town" landscapes. While "planning" is largely a dirty word in most of the West, many town councils will nevertheless enact restrictive architectural codes to maintain their chosen theme. Hunting, flyfishing, white-water rafting, snowmobiling, and other outdoor activities seem out of place to their participants if not anchored by a western town landscape. A town's visitors expect false-fronted stores, hitching posts, an occasional staged gunfight, wood-floored saloons, and old-looking signs. With the explosion of a tourist and recreation-based economy in the New West, these themed landscapes, or "themescapes," have proliferated and are now found throughout the recreation West.

One case in point is Winthrop, Washington, a quaint nineteenth century western theme town nestled up against the eastern slopes of the picturesque northern Cascade Mountains. Winthrop hasn't always looked this way though. In the 1960s, the owners of the local and struggling Wagner sawmill hired an architect to redesign Winthrop into an 1890s version of a frontier town in order to attract the visitors whom they hoped would soon be streaming in from Seattle over the new North Cascades Highway. The architect, not coincidently, came from the nearby and by then successful theme town of Leavenworth. The somewhat hypocritical architect wanted "to make the design as authentic as possible in order to preserve the spirit of the valley." Furthermore, in a convoluted connection fit for a Hollywood Western, Guy Waring, Winthrop's 1883 co-founder, was a Harvard roommate of Owen Wister, author of one of America's first western novels: The Virginian. The town of Winthrop claims that Wister penned the famous book after spending his honeymoon in town. Today, perhaps as a tribute to The Virginian and to western novels like it, Winthrop by law "now requires all new structures to meet the standards of the era spanning the years 1850-1900."17 Thanks to Wagner and his architect, visitors to Winthrop find hitching posts, watering troughs, false-fronted buildings, a rough-cut boardwalk, and no neon signs. So in Winthrop, like in so many western theme towns, residents have turned their backs on a town's authentic history in order to create a far more attractive (and profitable) past that entices visitors. And plenty of visitors make the journey to Winthrop to see the past as they think it was.

\subsection{Variations on a theme town}

\footnotetext{
14 Lew, A. "Defining Place Authenticity: My Heritage Can Beat Up Your History," Slideshare Presentation, http://www.slideshare.net/alew/defining-place-authenticity, accessed, January, 2016.

${ }^{15}$ Frenkel and Walton, "Bavarian Leavenworth...," 559-584.

${ }^{16}$ Best, A. (1998). "Vail and the road to a recreational empire," High Country News, December 7, 1.

17 Ordway, C.. "Western Towns Take You Back to Yesteryear," Northwest Travel Advisor, http://www.northwesttraveladvisor.com/northwest-vacation/western-towns.html, accessed, January, 2016. Winthrop, Washington, Chamber of Commerce. "Winthrop History," http://www.winthropwashington.com/history.html, accessed, January, 2016.
} 
While tourism has sanitized much of the West's unsightly nineteenth century landscapes, in some places the ugliness and precariousness are the attraction. The boom of nineteenth century western extractive towns often ended in bust as resources lay exhausted, whimsical markets disappeared, or technology changed. The rise and fall was often spectacular and sudden, and left behind were ghost towns. Laid out in 1905, Rhyolite, Nevada, suddenly came into being during a gold rush to the southern part of the state. Just one year later, in 1906, 10,000 people lived there. "In its brief prime," wrote historian Patricia Limerick, "it had everything - banks, women's organizations, churches, saloons, newspapers, schools, electricity, a railroad connection, and a sizeable train station." But by 1911, just five years later, the gold had run out and Rhyolite slumbered completely abandoned a ghost town. Today, some visitors find these relics of the Old West an ideal tourist destination. ${ }^{18}$

The West is particularly fond of its ghost towns. In the words of one historian, "there are, of course, failed towns everywhere, but the West made abandoned townsites into part of its capital."19 The state of Montana, for example, has an official Montana Ghost Town Preservation Society. Founded in 1969 and headquartered in Bozeman, it claims that the state has more than 600 ghost towns, and it draws enough interest and members to hold a convention every year. The 2008 gathering in Butte, Montana, drew lots of enthusiasts from out-of-state. ${ }^{20}$ Once the copper capital of the U.S., Butte itself has certainly seen a lot of economic bust, but Interstate 90 and rising copper prices have protected it from ghost town status. Nevertheless, to insure its viability, Butte also sells its abundant mining history and Victorian architecture to interested and eager tourists. Likewise, for many busted settlements, a tourist-based theme appears to be a viable alternative to remaining a real western ghost town. As it turns out, ghost town status alone, even if supported by an official society, does little economically for local residents and the places they call home.

With this bleak ghost town future in mind, some of the West's towns have simply refused to give up, and they want tourists to know it. Merchants in the dying silver town of Tombstone, Arizona, promoted their community with bumper stickers stating, "Tombstone: The Town Too Tough to Die." Not to be outdone, Bisbee, Arizona - located 25 miles south of Tombstone - printed, “Bisbee: The Town too Dumb to Die” and later, “Bisbee Arizona Ain't No Ghost Town!" With these slogans, residents of Tombstone and Bisbee hoped a healthy dose of western grit and determination could stave off economic bust and ghost town distinction. And predictably, they too choose a western theme as an economic development strategy to organize around (Francaviglia, 1991).

For some already extant ghost towns, tourism may be the next boom waiting to happen, even if the ghosts are not in favor of the conversion. Forty-five miles west of Butte is tiny Southern Cross, a long-abandoned gold mining town high up in the Montana Rockies. Southern Cross still had three full-time residents and nine seasonal inhabitants until the late 1990s. Or at least it had these dozen people until a development company bought the mining rights and served the denizens with eviction notices. The group of investors has a resort in mind, and real people living in Southern Cross are very definitely not part of their vision. According to one of the new owners, John Fitzpatrick of Helena, "The leading [development] candidate now is a neat little recreation complex, which would be integrated into a theme development, along the lines of a Western historical theme." Timothy Eagan, a New York Times reporter and author, captured Southern Cross's all-too-common experience when he wrote, "the West is full of ghost towns, little bunches of rusted structures and rotted hovels. From the outside, they tell a consistent story: boom, bust, abandon." But then, like Southern Cross, some of them get discovered, and "so the cycle goes - from live town, to ghost town, to revitalized theme town, cleaned of the messier elements of authenticity." 21 Clearly, people have very specific ideas about what history should look like, and as the New West strives to look like the Old West, sometimes it is hard to tell one from another. But not for everyone.

According to Bozeman, Montana, writer Ray Ring, it is easy to tell the busted Old West from the booming New West; one simply needs to visit the cemetery. For Ring, graveyard math suffices: if there are more graves than people currently living in town, the New West has not yet arrived and "if a town is more dead than alive, it's the Old West." The mining town of Anaconda, Montana, for example, counts 20,000 graves, twice the living population and definitely symptomatic of a busted Old West town. By contrast, 38,000 live in Bozeman, Montana, compared to about 6,000 resting in its cemetery. Bozeman is clearly part of the booming New West according Ring. ${ }^{22}$

Western theme town landscapes are a natural derivative of myth and image building by the media. Hollywood still films "shoot 'em up" Westerns, writers still spin tales about cowboys and Indians, painters and sculptors still depict the majestic Old West, and country music artists still wear cowboy hats and boots, and sing about the old

\footnotetext{
${ }^{18}$ Limerick, Patricia Nelson. (1992). “Haunted by Rhyolite,” American Art, September 22, 21.

${ }^{19}$ Limerick, "Haunted by Rhyolite," 21.

20 The Montana Ghost Town Preservation Society, http://mtghosttown.org/, accessed, January, 2016.

${ }^{21}$ Egan, T., (1998). "When Ghost Town Dies, What of the Ghosts?" The New York Times, May 4, U.S. Section.

${ }^{22}$ Ring, R. (1997). "If a town is more dead than alive, it's Old West," High Country News, August 18, 12.
} 
lifestyles. In fact, a Hollywood movie gives a theme town a high measure of legitimacy. In western Kansas for example, signs along Interstate 70 used to promote Fort Hays by reading, "Visit Historic Fort Hays, as Featured in the Movie Dances with Wolves." The Kevin Costner, Oscar-winning blockbuster had become a force of authenticity. Whether the history was accurate or not did not really matter. What mattered was that fans saw Fort Hays in the film and it looked right. ${ }^{23}$

National Parks may bestow an air of legitimacy on theme towns as well. A special breed of theme towns sprouts and grows along the roadways leading to major tourist destinations such as the parks. Kindly called "gateway towns," they are typically "tourist traps" designed to separate visitors from their money while in route to Yellowstone, Yosemite, or the Grand Canyon. The income potential is enormous. Springdale, Utah - a gateway town of 529 on the way to Zion National Park - sees 3 million people pass through during a typical tourist season. Springdale, like nearly every other gateway town, has adopted a western theme as appropriate for its place in the surrounding geography. Its theme is sort of "Frontier Southwestern" and the town's visitors expect it. ${ }^{24} \mathrm{~A}$ long list of such gateway-to-national park towns exists: Jackson and Cody, Wyoming; Moab and Panguitch, Utah; Cortez and Estes Park, Colorado; Tusayan, Arizona; West Yellowstone and West Glacier, Montana; and many more. They provide the last "services" before travelers enter the wilds of our country's spectacular national parks. So contrived are the gateway theme landscapes that town residents reside in more of an amusement park environment than a real town. They may not like it, but the income potential is hard to resist (Steffens, 1993).

\subsection{Behind the facade}

The rush of the West to embrace theme towns as economic and demographic salvation is not without its pitfalls however, and the negative attributes of the new boom are not entirely foreign. For many communities, an historic scenario revisits: get-rich-quick development schemes; lack of planning and regulation; contentious relationships between recent migrants and long-time residents; uneven economic distribution; arrival of repetitive franchise America; displacement of local control by distant decision making; higher taxes; development-driven sprawl; an explosively rising cost of living; and of course, the specter of bust. Furthermore, the surrounding natural environment may suffer new (ab)uses: trails, fishing holes, beaches, and campgrounds fill to capacity; litter, pollution, and habitat destruction increase; development mares scenery and solitude; and environmental degradation occurs.

The rejuvenation of historic ghost and other towns creates hybrid and often bizarre landscapes that blend the nineteenth century West with the contemporary West: strip malls juxtaposed with strip mines, condominiums with cow pastures, and ski racks with gun racks. An opaque and myopic view of western history, confused by Hollywood imagery, manifests itself in these new landscapes. Many towns rush to (re)create what the public expects. In Leavenworth, Washington, for example, two towns exist side by side: the Bavarian commercial district for tourists and the real Leavenworth for its citizens. According to one historian, a simple walk a block or two off the commercial strip reveals "[the] dramatic difference between the contrived retail corridor of its main streets and less obvious residential sections of town." Like many western theme towns, the tourist landscape has nothing to do with Leavenworth's actual culture and historic landscape, leaving residents with a feeling of disconnection. ${ }^{25}$ Only residents born before 1965 have a clear understanding of their hometown. For everyone else, it is a cultural schizophrenia: the real and the surreal. The geographers studying Leavenworth found residents asking "who or what are we? Are we going to become Bavarians? Are we going to be imposters the rest of our lives? What has become of Leavenworth? Is it still there beneath the facade? Or is the facade Leavenworth?"26 Questions this fundamental may leave some residents in a constant state of unease.

Proponents of theme building though, such as the national quarterly magazine, Next American City, laud Leavenworth's efforts as a genuine example of community organization and planning success. For them, "the commitment of Leavenworth's citizens to rebuild their town is visible to all but the most jaded and has contributed not only to a thriving tourist economy, but to the development of a community still deeply involved in enacting a collective vision for the town." (Kavage, 2003). Even academics have noted that a faux theme may be far easier to tolerate than the cycles of boom and bust and the environmental degradation that comes with Old West industries like mining. As the busted silver town of Kellogg, Idaho, contemplated copying Leavenworth's theme, one historian invented a conversation with one of its residents: 'So you have some reservations about going Bavarian,' one wants to say to the speaker from Kellogg. 'Would you have any reservations about going back to mining? Isn't a bit of Alpine bric-a-brac a small price to pay compared to those earlier prices of acid rain, pollution, deforestation, and cyclical economic collapse?" (Limerick, 1999). As can be expected, the good and bad dichotomy of theme

\footnotetext{
${ }^{23}$ Wrobel, "Introduction: Tourist, Tourism, and the Toured Upon,” 5-6.

${ }^{24}$ Hanscom, G., (1997). “Greens bulldoze a conservation effort,” High Country News, September 29, 75.

${ }^{25}$ Sudderth, "Leavenworth, Washington...," 74-82.

${ }^{26}$ Frenkel and Walton, "Bavarian Leavenworth...," abstract.
} 
town tourism is not as simple as it is often portrayed. So what is good for some in Kellogg, Idaho, is likely bad for others in town. This can pit residents against one another in what historian Hal Rothman called a "contest for the soul of a place, [and] a battle for the meaning of local identity."(Rothman, 2007).

Like Kellogg, other towns struggle to "sustain a place-rooted community" while promoting a tourist-based economy. For some, the loss of a "sense of place" - a deep and complex attachment to a particular location - is profound. After turning their backs on a town's real history, culture, and genuine landscapes, many residents question whether the shift to tourism was worth it. Compounding this unease is the proliferation of touristoriented industries that create primarily minimum wage jobs. Unlike many of the old West's mining, logging, and farming jobs, only a few people have experienced real wealth from the abandonment of the community's authentic past. Those that profit are the owners and investors and those who have the greatest control over decision making. The rest have simply changed economic masters. ${ }^{27}$ One common theme town complaint is the fundamental loss of control experienced by a rapidly growing town. Like the Old West, the New West's economy in many ways continues to be a colonial economy, with decisions made from afar and where visitors have little incentive to care about local conditions (Rothman, 1998; Engler, 1994). The region's abundant federal lands for example are administered from Washington, and many of its prominent tourist businesses are headquartered in the East not in the West. And almost all of its visitors come from somewhere else. Historian Hal Rothman went so far as to state that "tourism is the most colonial of colonial economies." (Rothman, 2001) Residents feel as though they have little influence over their destiny, and that the changes taking place are out of their hands.

\subsection{A deal with the devil}

Old West theme town tourism promises much but may deliver little long term as it forges significant change in western communities. The most striking of the changes is the upwardly-spiraling cost of living in a booming western town. Outdoor recreation destinations, gateway villages, heritage settlements, and gambling towns suffer from a profound lack of affordable housing. Nowhere is the cost more exorbitant than in mountain ski resorts. Aspen, Colorado, with its Victorian downtown and mountain backdrops is the quintessential example. This oncebusted mining town, high in the Rockies, is now the most expensive place to live in the United States. Billionaires have pushed out the millionaires as they vie for unimaginably expensive properties. Usually hemmed-in by public lands and vertical topography, ski resort building lots fetch premium prices. As the real estate agents' mantra espouses, "it's location, location, location." Former miner's cabins in Aspen routinely fetch several million dollars if they have a view; for many, that is on the order of $\$ 10$ per square inch of land. Most often, developers simply raze the old structures to make room for a "monster or trophy home." One recently completed in Aspen, contains 20,000 square feet of living space and retailed for $\$ 24.9$ million or $\$ 1245$ per square foot. ${ }^{28}$

Aspen's experience is replicated throughout the mountain West. Telluride and Silverton, Colorado; Park City, Utah; Jackson Hole, Wyoming; and Sun Valley, Idaho, have already been "Aspenized." Many towns are worried about following the same development pathway, even ones not usually associated with the premier resort destinations. Their residents say that the last thing they want to do is become another Aspen. But for many, it is too late. With development, their population is growing quickly and their town is quickly growing unaffordable. ${ }^{29}$

A virtual army of "hospitality workers" services these theme towns. They staff the lifts, clean the houses, wait tables in the restaurants, work at the convenience markets, and sell the shtick. Even with salaries two or three times minimum wage, they cannot begin to afford to live in the towns that demand their labor. Recently, no single family homes were available in Aspen for less than $\$ 700,000$. Even if affordable housing is available, cheap rent often defined as less than $\$ 1000$ per month - demands much of an employee's paycheck. The scramble for a roof over one's head leads to remarkable make-shift accommodations: tent camping, living in vehicles, renting sheds or garages, and even occupying floor space in a storage locker or warehouse. Forced out of town by high prices, many workers must commute - sometimes hundreds of miles and over snowy mountain passes to find affordable housing. Thus, a trickle-down effect diffuses around the West's premier theme towns. Neighboring villages, now burgeoning with immigrants, face a rising cost of living and similar problems of growth. For them, the bust seems nowhere in sight (Jaynes, 1994; Long, 2001; Kraker, 2008).

Even with rapid population growth and rising incomes, gaming towns must increasingly cope with a host of negative side effects. Charles McLean - president of the anti-gambling organization, Casino Free Future - has said that, "gambling brings all the impacts of boom development with none of the benefits." 30 Colorado's gaming towns now deal with increased traffic, crime, pollution, rising taxes, higher rents, and loss of local control. In fact, while

\footnotetext{
${ }^{27}$ Sudderth, “Leavenworth, Washington...," 80-81.

${ }^{28}$ Coleman, M. (1998). “The high end of home economics: Aspen's trophy home phenomenon,” High Country News, August $17,12$.

${ }^{29}$ Paradis, T. W. (2003). Theme Town: A Geography of Landscape and Community in Flagstaff, Arizona. Author House.

${ }^{30}$ National Civic Review. (1993). “Distressed Cities Increasingly Bank on Casino Gambling,” Volume 82, Number 3, Summer, $302-305$.
} 
gaming proponents argued that gambling funds would restore historic buildings, just the opposite has happened. The National Park Service placed all three Colorado towns - Black Hawk, Central City, and Cripple Creek - on its list of most endangered historic landmarks. Overwhelmed by new construction, the old edifices faced demolition or demand for improved infrastructure. Likewise, significant social costs strain the gambling towns with rising crime rates, substance abuse, weakening of the social fabric, and loss of community. When asked in a survey if they agreed with the statement "My town is an ideal place to live," 76 percent of Central City and 56 percent of Cripple Creek residents expressed strong disagreement. Furthermore, 39 percent and 44 percent of the residents said they would consider moving away from Central City and Cripple Creek respectively. Clearly, the towns' gamble did not pay off for these residents (Long, et al., 1994).

Additionally, many of the casinos are controlled by outside owners who began to leverage the communities and demand government concessions. Their threat: if you do not give us what we want (tax holidays, subsidized utilities, and zoning variances for example), we will pull out of town and go somewhere else (Whittington, 1996). Perhaps most troubling is the projected gaming slump. Nearly half of the nation's 562 Indian tribes possess some form of gambling. Experts agree that as more towns and reservations add gambling facilities, the market will reach saturation and become predatory; for any single town to gain visitors, another will have to give some up. Erroneously, in a high-stakes gamble, most towns, like the Colorado trio, are betting this won't happen to them. If dealt a bad hand of cards though, economic and demographic bust may once again return to haunt these citizens of the small town West. ${ }^{31}$

Moreover, if the original stimulus for western tourism, transportation, can found towns, it can just as quickly bring on their demise. Many railroad towns whose tracks are now quiet and two-lane highway towns, now bi-passed by an Interstate, lie dormant. Towns along historic Route 66 and Highway 50 in Nevada - known now as "the Loneliest Road in America" - pine away for the visitors and the vitality they once enjoyed generations ago. It is likely that no amount of historic theme huckstering in Cold Springs, Austin, and Eureka, Nevada, will rejuvenate them, even if they do have a historic theme to rally around.

Furthermore, in an increasing conflict of interest, academics have also found western theme towns to be good for business. Cultural Conservation and Heritage Tourism have served as a boon to historical geographers, preservationists, historians, and anthropologists; many towns hire these professionals to help guide them toward refurbishing their historical landscapes. The work does raise ethical concerns however, about the appropriateness, accuracy, and conversion of heritage and culture to commodities. Consultants find that too often tourist needs and entrepreneurial desires drive the restoration process, and accuracy gets sacrificed for accessibility, attractiveness, and money-making ability (Howell, 1994). In 2008, Virginia and Nevada City in Montana undertook an ambitious and comprehensive "Historic Site Development Plan." While the plan admirably calls for stabilizing and preserving buildings and caring for historic artifacts, it is clearly a vision for economic development more than anything else. Of particular emphasis is the plan's encouragement of the towns' transition from one-season to three-season destinations, which, if completed, would draw even more visitors. How this will help preserve the area's many historical structures and natural environment is obviously a tenuous argument. ${ }^{32}$

\subsection{Commonplace}

Twentieth century theme towns grew out of a combination of earlier outdoor historical museums, amusement parks, and theme parks. Today, they try to successfully meld recreation, tourist accommodations, and western heritage. Those depicting 19th century landscapes - either real or perceived - are the most successful. These western theme towns draw visitors and new residents alike, enjoy expanding economies, and rising tax revenues. They have become so successful in fact, that western theme towns are now exported to the East. Residents of Ocean City, Maryland, need not travel very far to "experience" the West. "Frontier Town", Maryland, and its "Western Theme Park" encourage visitors to "C'mon down folks...to our replica western town circa 1860 situated alongside of Frontier Town Campground and ...lose yerself in the thick atmosphere of the Ol' West.33 Not far away, in Netcong, New Jersey, travelers can visit "Wild West City", which boasts of being "The Best of the West in the Heart of the East." Westerners may bristle at the idea of the creation of an Old West town in the East, but the only difference between Wild West City and the many western theme towns is their location. For 56 years, Wild West City has been "a western heritage theme park that brings the old west back to life...offer[ing] the visitor the chance to "live' in the old west!" 34 With a mission really no different than any of the many theme towns that actually reside in the American West, Frontier Town and Wild West City endeavor to "give 'em what they want"

\footnotetext{
${ }^{31}$ National Civic Review. (1993). “Distressed Cities...” 302-305.

32 Montana Heritage Commission, "Virginia City: Historic Site Development Plan,” http://www.virginiacitymt.com/, accessed, January, 2016.

33 Frontier Town Campground, "Western Theme Town," Ocean City, Maryland USA, homepage: http://www.frontiertown.com/index.cfm, accessed, January, 2016.

${ }^{34}$ Wild West City, New Jersey, homepage: http://www.wildwestcity.com/, accessed, January, 2016.
} 
or at least what they expect. In a great irony, "Frontier Town," New York, a popular tourist destination for half a century, went bust in the early 2000s when its assets were seized to pay back taxes, and its lands, buildings, and props were placed up for auction. Like anywhere else, Frontier Town's boom was just the interlude in the journey to bust (Liquori, 2004).

As tourism, recreation, and retirement continue to dominate the economy of the New American West, the proliferation of theme towns will surely continue. One must ask though, at what cost? Will the region's residents be able to avoid selling out their heritage and culture as they pursue the mighty visitor dollar? Will they will be able to afford to live in the "Real West" towns they are rapidly creating? And furthermore, will they really want to live in these places? Ironically, the success of theme towns may be their undoing. Much of the attraction to a theme town centers on its uniqueness. Drawn to a pleasant and unusual landscape, visitors often travel great distances to partake in what they believe is an uncommon experience. With the proliferation of theme architecture and ambience however, the experience is no longer unique. It has almost become a franchised landscape: mundane, banal, and commonplace, a "geography of nowhere" in particular author James Kunstler would assert. ${ }^{35}$ Western themes are now no farther than the local strip mall or suburban shopping district for some potential visitors. They need not travel to find them, which calls into question the very essence of most western theme towns: without a firm sense of place and time, they are much more about what people expect rather than what actually existed. They may be economically successful, but for many, the tradeoffs make them no place to live contentedly in the New American West. And for some towns like Steins, New Mexico, boom may never replace the long dormancy of bust.

\subsection{Conclusions and policy implications}

As was thoroughly detailed in this paper, the adoption of an Old West theme may bring profitable relief to a community trapped in the malaise of a moribund, primary industry-dominated economy. When farming, mining, logging, and ranching have run their course, many towns struggle to retain businesses and residents, and remain viable. With the explosive growth of tourism, outdoor recreation, mobile retirees, and technology-enabled pioneers, however, many struggling places may find the allure of the next growth-fueled boom irresistible. And it may seem that embracing a western theme to attract new vitality is a small concession to make when faced with the continuation of economic and demographic bust. Nevertheless, community leaders, city planners, economic development experts, and residents alike would be wise to carefully consider the costs and benefits before making such a transformation. Proponents of change should analyze the many implications of such a conversion: rising cost of living and property values; loss of true history and culture; outside ownership and control; rapid population growth, urban sprawl, and pressure on city services and infrastructure; replacement of local businesses with franchises; decline of rural character and a close-knit community; and lastly, the many environmental impacts such as pollution, development of open space, and depletion of water resources. Furthermore, as discussed earlier, there is no guarantee that a conversion to a theme town will actually succeed, nor that the growth it may engender will last. In many ways, the boom-bust cycle is every bit as integral to the story of the mythical American West as were cowboys and saloons. We just tend to focus on the more romantic portions of that story. Clearly then, community leaders, planners, and policy makers need to be more realistic than romantic if they want to build sustainable places in the American West where people want to live, work, and visit.

\section{References}

Athearn, Robert G. (1986). The Mythic West in twentieth-century America. Lawrence: University Press of Kansas. Barrett, W. P. (1993). "The Bordello is Over There, Steins, New Mexico," Forbes, September 13, $1993,178$. Claridge, Drusilla. (2003). "Steins - a Railroad Ghost Town," http://www.southernnewmexico.com/Articles/Southwest/Hildago/Steinsrailroadghosttown.html, accessed, January, 2016. Steins Homepage: http://steinsnmrailroadghosttown.webs.com/, accessed, January, 2016.

Blake, Kevin. (2014). "Making Mythic Landscapes," Wyckoff, William. (2014). "Creating Region Landscapes and Identities" and Youngs, Yolanda. (2014). "Shaping Tourism" in Craig E. Colton and Geoffrey L. Buckley, eds. North American Odyssey: Historical Geographies for the Twenty-first Century. Lanham, Maryland: Rowman \& Littlefield.

Boyer, M. C., (1992). “Cities for Sale: Merchandising History at South Street Seaport” in Michael Sorkin, Editor, Variations on a Theme Park: The New American City and the End of Public Space. New York: Hill and Wang, 181-204.

Bryson, B., (1989). The Lost Continent: Travels in Small-Town America. New York: Harper Perennial, 108-112.

${ }^{35}$ Kunstler, J. (1993). The Geography of Nowhere: The Rise and Decline of American's Man-Made Landscape. New York: Simon and Schuster. 
DeLyser, D. (1999). "Authenticity on the Ground: Engaging the Past in a California Ghost Town," Annals of the Association of American Geographers, 89(4): 602-632.

DeLyser, D. (2003). "Ramona Memories: Fiction, Tourist Practices, and Placing the Past in Southern California," Annals of the Association of American Geographers, 93(4): 886-908.

Engler, M. (1994). “Theme Towns: The Pitfalls and Alternatives of Image Making," Small Towns Institute, Jan-Feb., 14-23.

Ewert, E. C. (2006). "From Hinterland to Bellwether: A Century of Demographic and Economic Change in the Pacific Northwest," The Journal of the West, Vol. 45, No. 1, Winter, 41-51.

Francaviglia, R. V. (1991). Hard Places: Reading the Landscape of America's Historic Mining Districts. Iowa City: University of Iowa Press, 177-179.

Francaviglia, R. V. (1994). "Victorian Bonanzas: Lessons From the Cultural Landscape of Western Hard Rock Mining Towns," Journal of the West, January, 53-54.

Francaviglia, R. (2000). "Selling Heritage Landscapes" in Arnold R. Alanen and Robert Z. Melnick, eds, Preserving Cultural Landscapes in America. Baltimore: The Johns Hopkins University Press.

Frenkel, S. and Walton, J. (2000). "Bavarian Leavenworth and the Symbolic Economy of a Theme Town," The Geographical Review, October, 559-584.

Hausladen, G. J. (2006). Western Places, American Myths: How We Think about the West. Reno, NV: University of Nevada Press.

Howell, B. J. (1994). "Weighing the Risks and Rewards of Involvement in Cultural Conservation and Heritage Tourism," Human Organization, Vol. 53, No. 2, June 22, 150.

Jaynes, G. (1994). “Down and Out in Telluride," Time, September 5, 61-62. Best, Allen. (1998). "Vail and the road to a recreational empire," High Country News, December 7, 10-15;

Kavage, S., (2003). "The Marketing of Place: How Bavaria Came to Leavenworth, WA," The Next American City Magazine, Issue 02, June.

Kraker, D. (2008). “Around Resorts, Boomlet Towns Thrive, Too,” Morning Edition, National Public Radio, August 20.

Limerick, P. N. (1999). "Seeing and Being Seen: Tourism in the American West," in Valerie J. Matsumoto and Blake Allmendinger, eds., Over the Edge: Remapping the American West. University of California Press, 28.

Liquori, D. (2004). “A Western Theme Park Turns Into a Ghost Town,” New York Times, Vol. 154, p B3, October 18.

Long, P. T. (2001). “For Residents and Visitors Alike: Seeking Tourism's Benefits, Minimizing Tourism's Costs," in David M. Wrobel and Patrick T. Long, eds., Seeing and Being Seen: Tourism in the American West. University of Kansas Press, 75-76.

Long, P., Clark, J. and Liston, D. (1994). Win, Lose or Draw! Gambling with America's Small Towns. Washington, D.C.: Aspen Institute.

Manning, E., (1996). “Deadwood pays dearly for gambling riches,” High Country News, April 1, 11-13.

Ordway, C.. "Western Towns Take You Back to Yesteryear," Northwest Travel Advisor, http://www.northwesttraveladvisor.com/northwest-vacation/western-towns.html, accessed, January, 2016. Winthrop, Washington, Chamber of Commerce. "Winthrop History," http://www.winthropwashington.com/history.html, accessed, January, 2016.

Piner, Judie M. and Paradis, Thomas W. (2004). "Beyond the Casino: Sustainable Tourism and Cultural Development on Native American Lands," Tourism Geographies 6(1), 80-98.

Price, T. and Miller, J. (1997). Miracle Town: Creating America's Bavarian Village in Leavenworth, Washington. Price \& Rodgers.

Rothman, H., (1996). "Selling the Meaning of Place: Entrepreneurship, Tourism, and Community Transformation in the Twentieth-Century American West," Pacific Historical Review, Volume 65, Number 4, November, 525558.

Rothman, H. K. (1998). Devil's Bargains: Tourism in the Twentieth-Century American West. Lawrence: University Press of Kansas, 10-11.

Rothman, H. K. (2007). Playing the Odds: Las Vegas and the Modern West. Albuquerque: University of New Mexico Press, 140.

Rothman, H. K. (2001). "Shedding Skin and Shifting Shape; Tourism in the Modern West," in David M. Wrobel and Patrick T. Long, eds., Seeing and Being Seen: Tourism in the American West. University of Kansas Press, 102.

Spude, R. L. (1996). "Looking Back at 'The Rush to the Rockies': Preserving Four 1860s Gold Camps," Journal of the West, October, 8.

Steffens, R. (1993). "Not Just Another Roadside Attraction," National Parks, Volume 67, Nos. 1-2, JanuaryFebruary, 26-32.

Sudderth, J. (1997). “Leavenworth, Washington: a Study in Landscape Evolution,” Journal of the West, October, 74-82.

Wilson, C., (1997). The Myth of Santa Fe: Creating a Modern Regional Tradition. University of New Mexico Press, 110-145. 
Whittington, B. (1996). “Goodbye, Deadwood,” High Country News, April 1, 13.

Wrobel, D. M. (2001). "Introduction: Tourist, Tourism, and the Toured Upon,” in David M. Wrobel and Patrick T. Long, eds., Seeing and Being Seen: Tourism in the American West (University of Kansas Press, 19-20.

Wrobel, D. M. (2002). Promised lands: promotion, memory, and the creation of the American West. Lawrence, KS: University Press of Kansas.

Williams, Stephen, and Alan A. Lew. (2014). Tourism Geography: Critical Understandings of Place, Space and Experience, Third Edition. New York: Routledge. 